Zeszyty Naukowe Szkoły Głównej Gospodarstwa Wiejskiego w Warszawie

Problemy Rolnictwa Światowego tom 17 (XXXII), zeszyt 1, 2017: 19-30

DOI: 10.22630/PRS.2017.17.1.2

Katarzyna Czech $^{1}$, Michał Wielechowski ${ }^{2}$

Szkoła Główna Gospodarstwa Wiejskiego w Warszawie

\title{
Brexit a sytuacja ekonomiczna Wielkiej Brytanii
}

\section{Brexit and United Kingdom Economic Situation}

\begin{abstract}
Synopsis. Celem artykułu jest przedstawienie wpływu wyniku referendum z 23 czerwca $2016 \mathrm{r}$. dotyczącego wyjścia Wielkiej Brytanii z Unii Europejskiej na stan gospodarki i finansów tego kraju. Publikacja zawiera przegląd światowej literatury i prasy ekonomicznej odnoszących się do kwestii następstw decyzji Brytyjczyków o opuszczeniu struktur unijnych. W artykule przedstawiono, że wynik referendum przyczynił się do wystapienia rekordowych poziomów indeksu niepewności polityki gospodarczej (EPU) w Wielkiej Brytanii. Wysoki poziom niepewności ekonomicznej i finansowej wywarł w konsekwencji negatywny wpływ na kondycję brytyjskiej gospodarki. W artykule pokazano wpływ wyniku referendum na wartość brytyjskiej waluty, poziom podstawowych wskaźników makroekonomicznych, poziom aktywności gospodarczej w sektorze wytwórczym oraz sferę finansów publicznych. Kurs funta szterlinga w odniesieniu do dolara amerykańskiego i euro uległ silnej deprecjacji i spadł poniżej poziomów osiaganych w trakcie ataku spekulacyjnego przeprowadzonego przez George'a Sorosa w 1992 r., inwazji na Irak w 2003 r., czy kryzysu finansowego w latach 2008-2009. Wynik referendum można łączyć ze wzrostem inflacji oraz spadkiem tempa wzrostu PKB. Wielka Brytania zdecydowała się na wprowadzenie bardziej ekspansywnej polityki monetarnej poprzez obniżenie poziomu bazowej stopy oraz rozszerzenie programu luzowania ilościowego. Poziom aktywności gospodarczej w sektorze wytwórczym uległ krótkookresowemu obniżeniu $\mathrm{w}$ konsekwencji wyniku referendum. Perspektywa Brexitu miała również negatywny wpływ na stan brytyjskich finansów publicznych. Wysokość prognozowanego ujemnego salda finansów publicznych w 2017 r. wzrosła o ponad 30 proc., a minister finansów zmuszony był odstapić od realizacji ambitnego celu eliminacji deficytu budżetowego do roku fiskalnego 2019-2020.
\end{abstract}

Slowa kluczowe: Brexit, indeks niepewności polityki gospodarczej (EPU), funt szterling, indeksy aktywności gospodarczej w sektorze wytwórczym (PMI), gospodarka i finanse publiczne Wielkiej Brytanii

\begin{abstract}
On 23th June, 2016, British voters decided in a referendum to cut long-term relationship with the European Union. The aim of a paper is to present the impact of UK's Brexit vote on the British economy. The paper depicts review of international scientific literature and economic press concerning the vast range of issues affected by Brexit. It has been shown that the British referendum outcome caused the growth of uncertainty about economy of the United Kingdom. Economic Policy Uncertainty Index reached British record-high levels in post-referendum period. Growing economic and financial uncertainty had negative effects on British economic activity. The paper presents the impact of the referendum on British currency, fundamental macroeconomic indicators, economic activity in manufacturing, and public finance. It has been shown that, in post-referendum period, the pound sterling plunged the depths it had reached after the speculative attack on pound sterling led by George Soros in 1992, after invasion of Iraq in 2003 and during financial crisis in 2008-2009. British referendum outcome contributed also to inflation rate increase and GDP growth rate decrease. Thus, the United Kingdom decided to implement more expansionary monetary policy by cutting interest rates and increasing quantitative easing. As a result of the referendum, the level of economic activity in the manufacturing sector went shortly down. Britain's vote to leave the EU had also a negative
\end{abstract}

\footnotetext{
${ }^{1}$ dr, Katedra Ekonomiki Rolnictwa i Międzynarodowych Stosunków Gospodarczych SGGW w Warszawie, ul. Nowoursynowska 166,02-787 Warszawa, e-mail: katarzyna_czech@sggw.pl

${ }^{2} \mathrm{dr}$, Katedra Ekonomii i Polityki Gospodarczej SGGW w Warszawie, ul. Nowoursynowska 166,

02-787 Warszawa, e-mail: michal_wielechowski@sggw.pl
} 


\begin{abstract}
impact on British public finances. The forecasted general government deficit in 2017 increased by more than 30 percent. Chancellor of the Exchequer was forced to abandon the ambitious goal of eliminating the negative balance by fiscal year 2019-2020.
\end{abstract}

Key words: Brexit, Economic Policy Uncertainty Index, pound sterling, Purchasing Managers' Indexes, British economy and public finance

\title{
Wprowadzenie
}

Wynik referendum z 23 czerwca 2016 r. odnoszącego się do kwestii dalszego członkowska Wielkiej Brytanii w Unii Europejskiej (zwanego w dalszej części artykułu referendum) zszokował ekonomiczną i polityczną opinię publiczną na całym świecie. Większość ekonomistów, praktyków finansowych, jak i najważniejszych światowych graczy politycznych wspierała w kampanii przedreferendalnej zwolenników Bremainu (pozostania Wielkiej Brytanii $w$ strukturach UE), wskazując wiele racjonalnych argumentów. Jednakże, skutecznie przeprowadzona kampania polityczna zwolenników Brexitu (wyjścia Wielkiej Brytanii z UE) spowodowała, że 52 proc. głosujących Brytyjczyków opowiedziała się za odłączeniem się od struktur europejskich (Theresa May kicks..., 2016, Wielechowski, Czech, 2016). Pierwszy w historii przypadek, kiedy państwo członkowskie Unii Europejskiej zdecydowało się na wyjście z UE, stał się przedmiotem badań ekonomistów, politologów i finansistów z wielu ośrodków naukowych na całym świecie.

Celem artykułu jest przedstawienie wpływu wyniku referendum dotyczącego wyjścia Wielkiej Brytanii z Unii Europejskiej na stan gospodarki i finansów tego kraju. Artykuł został podzielony $\mathrm{w}$ następujący sposób. W sekcji pierwszej przedstawiono zmianę poziomu niepewności w brytyjskiej gospodarce, mierzonego indeksem niepewności polityki gospodarczej - EPU. W części drugiej dokonano analizy danych historycznych kursów walutowych funta brytyjskiego do dolara amerykańskiego i euro w latach 19992017 oraz zaprezentowano wpływ kluczowych wydarzeń historycznych, w tym referendum z dnia 23 czerwca 2016 r, na wartość funta szterlinga. W sekcji tej przedstawiono także prognozy dotyczące kształtowania się kursu walutowego USD/GBP w latach 2017-2020. $\mathrm{W}$ części trzeciej poddano analizie historyczne i prognozowane wartości mierników makroekonomicznych, mianowicie Produktu Krajowego Brutto (PKB) oraz inflacji mierzonej indeksem cen dóbr i usług konsumpcyjnych (CPI). Przedmiotem czwartej sekcji były zmiany poziomu aktywności gospodarczej w sektorze produkcyjnym Wielkiej Brytanii mierzonego indeksem PMI. W piątej sekcji dokonano analizy sytuacji finansowej Wielkiej Brytanii, zwracając uwage na istotne zmiany prognozowanej wartości deficytu sektora finansów publicznych. W części ostatniej zostały zaprezentowane wnioski.

\section{Wzrost niepewności w gospodarce Wielkiej Brytanii}

Ryzyko spowolnienia gospodarczego wywołanego Brexitem spowodowało zwiększenie zmienności cen na rynku finansowym, szczególnie cen funta szterlinga. Występowanie trudności w budowie prognoz dotyczących wpływu Brexitu na przyszłość brytyjskiej gospodarki, wskazuje na problem ogromnej niepewności polityki gospodarczej Wielkiej Brytanii (Wielechowski, Czech, 2016). Poziom niepewności gospodarczej można 
określić na podstawie wartości indeksu niepewności polityki gospodarczej — EPU (ang. Economic Policy Uncertainty Index), który został opracowany przez Bakera, Blooma i Davisa (Baker i in., 2015; Baker i in., 2016).

Do budowy EPU wykorzystane zostały trzy rodzaje komponentów bazowych. Pierwszy składnik mierzy zainteresowanie prasy ekonomicznej problemem niepewności związanej z polityką gospodarczą. Drugi składnik odzwierciedla liczbę przepisów prawa podatkowego, które stracą ważność w przyszłych latach. Trzeci komponent uwzględnia niejednorodność prognoz gospodarczych wśród ośrodków ekonomicznych. Wzrost wartości indeksu oznacza występowanie zwiększonej niepewności polityki gospodarczej (Economic Policy Uncertainty 2017). Rys. 1 prezentuje zmiany kształtowania się poziomu wskaźnika niepewności polityki gospodarczej w Wielkiej Brytanii, począwszy od stycznia 2000 r. do stycznia 2017 r.

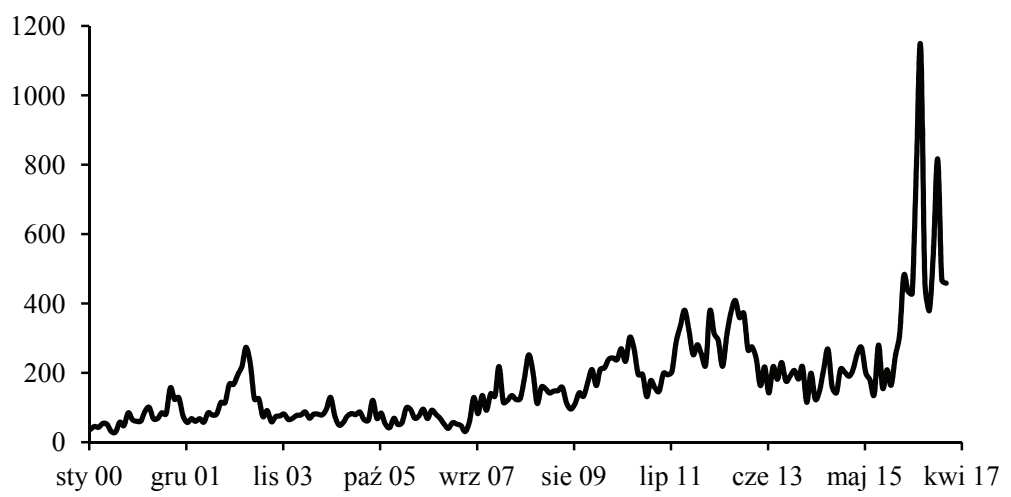

Rys. 1. Wskaźnik niepewności polityki gospodarczej w Wielkiej Brytanii w okresie 01.2000-01.2017

Fig. 1. Economic Policy Uncertainty Index for the United Kingdom in the period 01.2000-01.2017

Źródło: opracowanie własne na podstawie danych Economic Policy Uncertainty.

W analizowanym okresie zaobserwowano kilka ekstremów wartości EPU. Inwazja na Irak w marcu 2003 r. była bezpośrednią przyczyną znaczącego wzrostu indeksu do poziomu ok. 275 pkt. Bankructwo banku Lehman Brothers we wrześniu 2008 r., uznawane za początek kryzysu finansowego w USA, wywołało wzrost indeksu do poziomu ponad 250 pkt. W najgłębszej fazie kryzysu ekonomicznego w strefie euro, tj. w listopadzie 2012 r., wartość EPU przekroczyła 400 pkt. Jednakże, wynik referendum z 23 czerwca 2016 r. wywołał niespotykany wcześniej wzrost niepewności polityki gospodarczej w Wielkiej Brytanii. W momencie ogłoszenia terminu referendum przez Davida Camerona, ówczesnego premiera, poziomi EPU wynosił ok. 300 pkt. W okresie 03.2016-06.2016 nastapił stopniowy silny wzrost poziomu EPU do ok. 800 pkt. Niespodziewany rezultat referendum wywołał gwałtowne zwiększenie wskaźnika niepewności polityki gospodarczej w Wielkiej Brytanii do rekordowego poziomu 1142 pkt. Nieznajomość przyszłej relacji pomiędzy Unią Europejską a Wielką Brytanią powodowała utrzymywanie bardzo wysokiej wartości indeksu niepewności polityki gospodarczej.

Steinberg (2017), wykorzystując dynamiczne modele równowagi ogólnej, zaobserwował, że całkowite koszty spowodowane Brexitem będą wynosić pomiędzy 7000 
a 18000 funtów szterlingów w przeliczeniu na jednego mieszkańca Wielkiej Brytanii, niezależnie od formy przyszłej relacji z Unią Europejską ( $\mathrm{tj}$. wystąpieniem twardego bądź łagodnego Brexitu). Premia za ryzyko rekompensująca występująca niepewność w brytyjskiej gospodarce po Brexicie została wyceniona na zaledwie 45 GBP na obywatela (Steinberg 2017). Premia za ryzyko stanowi maksymalną ilość kapitału, jaką jednostka z awersją do ryzyka jest skłonna zapłacić, za jego wyłączenie (Jehle, Reny, 2000). Można zatem uznać, że pomimo tak wysokiej niepewności polityki gospodarczej Wielkiej Brytanii, obywatel tego kraju jest skłonny zapłacić jedynie niewielką część swojego kapitału za wyeliminowanie tego ryzyka.

\section{Deprecjacja funta brytyjskiego}

Jak wskazują Plakandaras i inni (2016), wysoki poziom niepewności gospodarczej spowodowany możliwością realizacji Brexitu, stanowił przyczynę bardzo silnej deprecjacji brytyjskiej waluty. Rys. 2 przedstawia kształtowanie się kursów walutowych EUR/GBP oraz USD/GBP w okresie $01.1999-01.2017$. W analizie przyjęto poprawny matematycznie zapis kursu walutowego w kwotowaniu bezpośrednim, tj. w liczniku znajduje się waluta kwotowana a w mianowniku waluta bazowa (Czech, 2016). Wzrost/spadek kursów walutowych EUR/GBP i USD/GBP oznacza aprecjacje/deprecjację funta szterlinga względem, odpowiednio euro oraz dolara amerykańskiego.

Zaprezentowane na rys. 2 dane wskazuja, że wynik referendum wywołał znaczne obniżenie wartości funta brytyjskiego względem euro oraz dolara amerykańskiego. Rekordowo niskie poziomy zaobserwowano w przypadku kursu USD/GBP. Perspektywa Brexitu spowodowała, że kurs USD/GBP spadł poniżej poziomów osiaganych w trakcie ataku spekulacyjnego przeprowadzonego przez George'a Sorosa w 1992 r., inwazji na Irak w 2003 r., czy też kryzysu finansowego w latach 2008-2009 (Krugman i in., 1999; Truman, 2002).

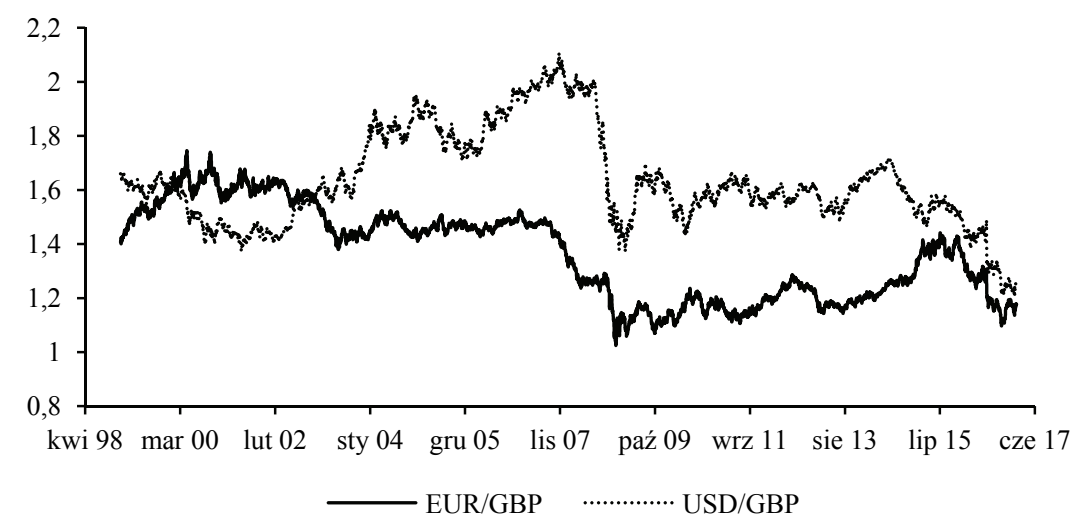

Rys. 2. Kształtowanie się kursów walutowych EUR/GBP oraz USD/GBP w okresie 01.1999-01.2017

Fig.2. EUR/GBP and USD/GBP exchange rates volatility in the period 01.1999-01.2017

Źródło: Opracowanie własne na podstawie danych Bloomberg. 
24 czerwca 2016 r., dzień po referendum, wartość funta szterlinga względem dolara amerykańskiego obniżyła się aż o 11,1 proc. Kolejny gwałtowny spadek kursu USD/GDP odnotowano w październiku 2016 r., bezpośrednio po zapowiedzi Theresy May, brytyjskiej premier, możliwości realizacji procedury całkowitego wyjścia Wielkiej Brytanii z Unii Europejskiej, tj. twardego Brexitu (May warned..., 2016). Wartość brytyjskiej waluty w stosunku do euro i dolara amerykańskiego osiagnęła wówczas rekordowo niskie poziomy. Warto zauważyć, że w okresie od referendum do października 2016 r., poziom brytyjskiego indeksu akcji FTSE 100 był w trendzie wzrostowym. Nie można wskazać jednoznacznej przyczyny wzrostu indeksu giełdowego, jednakże skład FTSE 100, bazujący na globalnych przedsiębiorstwach osiagających zyski głównie z pozabrytyjskich rynków, wskazywać może na możliwe wyższe pozytywne wyniki finansowe z międzynarodowej działalności handlowej (Wielechowski, Czech, 2016). Deprecjacja funta brytyjskiego była bowiem korzystna dla eksporterów. Z drugiej strony, w tym samym okresie (07.201610.2016), akcje instytucji sektora finansowego, przede wszystkim europejskich banków, odnotowały gwałtowne krótkoterminowe spadki. Schiereck i inni (2016) zaobserwowali, że skala spadku wartości rynkowej banków w okresie pierwszych 120 dni następujących po terminie referendum była wyższa nawet od giełdowych konsekwencji upadku banku Lehman Brothers w Stanach Zjednoczonych w dniu 15 września 2008 r. (również w okresie pierwszych $120 \mathrm{dni}$ ).

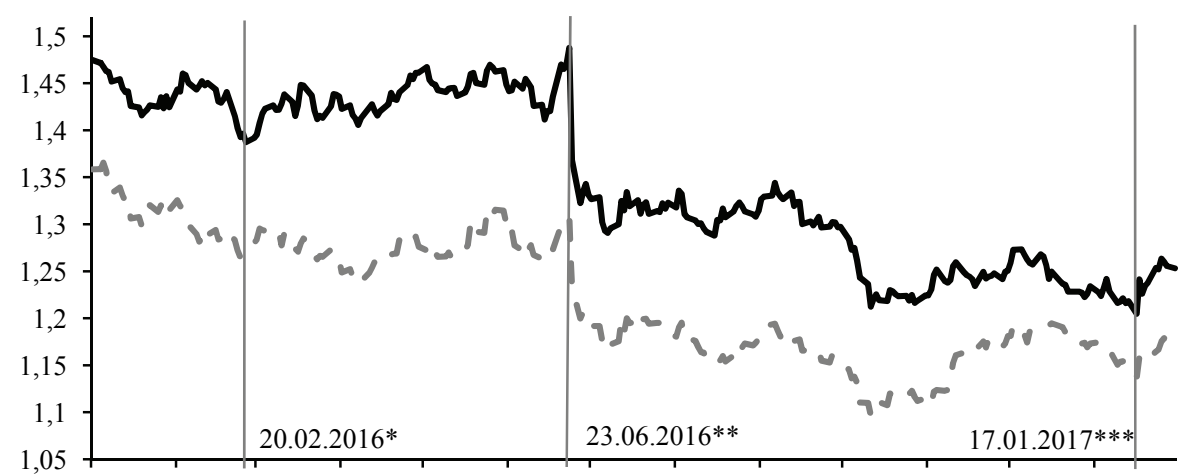

sty 16 lut 16 mar 16 kwi 16 maj 16 cze 16 lip 16 sie 16 wrz 16 paź 16 lis 16 gru 16 sty 17

$$
- \text { - EUR/GBP USD/GBP }
$$

*ogłoszenie daty referendum przez Davida Camerona, premiera Wielkiej Brytanii

** data referendum

***ogłoszenie twardego Brexitu jako przyszłej formy relacji z Unią Europejską przez Theresę May

Rys. 3. Kształtowanie się kursów walutowych EUR/GBP oraz USD/GBP w okresie 01.2016-01.2017

Fig.3. EUR/GBP and USD/GBP exchange rates volatility in the period 01.2016-01.2017

Źródło: opracowanie własne na podstawie danych Bloomberg.

Utrzymująca się niepewność na rynku walutowym, związana z brakiem jednoznacznej deklaracji odnoście charakteru przyszłej relacji Wielka Brytania - Unia Europejska ze strony brytyjskich władz, spowodowała, że kurs funta szterlinga w okresie 10.201601.2017 poruszał się $\mathrm{w}$ trendzie horyzontalnym (rys. 3). Odwrócenie trendu, tj. wzrost 
kursu funta szterlinga w odniesieniu do dolara amerykańskiego i euro, można łączyć z zajęciem jednoznacznego stanowiska $\mathrm{w}$ sprawie przyszłej formy relacji pomiędzy Wielką Brytanią a Unią Europejską, wygłoszonym przez Theresę May w dniu 17 styczniu 2017 r. Decyzja o realizacji twardego Brexitu przyczyniła się do obniżenia presji deprecjacyjnej na brytyjską walutę (rys. 3).

W tabeli 1 zaprezentowano prognozy dotyczące kształtowania się kursu walutowego USD/GBP w latach 2017-2020. Statystyki opisowe zostały oszacowane na podstawie prognoz budowanych przed i po referendum przez wiodace światowe instytucje finansowe, m.in. Westpac Banking, Citigroup, Credit Suisse Group, ING Financial Markets, JPMorgan Chase, Prestige Economics LLC, Barclays, Maybank Singapore, Norddeutsche Landesbank, Rabobank, Bank of America Merill Lynch, Morgan Stanley, Standard Chatered, ABN Amro, BNP Paribas, Royal Bank of Scotland, HSBC. Analizowane dane pokazują, że prognozy pochodzące $\mathrm{z}$ okresu poprzedzającego referendum, tj. $\mathrm{z}$ maja $\mathrm{i}$ czerwca 2016 r., wskazywały na stopniowa, stabilną aprecjację funta szterlinga względem dolara amerykańskiego $\mathrm{w}$ latach 2017-2020. Wynik referendum spowodował istotne zmiany w prognozach ww. instytucji finansowych. Groźba Brexitu wpłynęła na silne obniżenie prognozowanego kursu USD/GBP w 2017 r., w konsekwencji czego przeciętna wartość USD/GBP prognozowana na 2017 r. uległa obniżeniu o ok. 20 proc.(z poziomu 1,5 do 1,22). Prognozowany po referendum trend aprecjacji brytyjskiej waluty w stosunku do amerykańskiego dolara na lata 2018-2020 nie kompensuje strat spowodowanych wynikiem referendum (tab. 1).

Tabela 1. Prognozy dotyczące kształtowania się kursu walutowego USD/GBP w latach 2017-2020

Table 1. Leading financial institutions forecasts on USD/GBP exchange rate in the period 2017-2020

\begin{tabular}{c|ccccc}
\hline Statystyki opisowe & Czas prognozy & 2017 & 2018 & 2019 & 2020 \\
\hline \multirow{5}{*}{ średnia arytmetyczna } & 23.05 .2016 & 1,50 & 1,55 & 1,57 & 1,63 \\
& 23.06 .2016 & 1,50 & 1,55 & 1,58 & 1,65 \\
& 23.07 .2016 & 1,32 & 1,40 & 1,50 & 1,58 \\
& 23.09 .2016 & 1,31 & 1,37 & 1,40 & 1,52 \\
& 23.01 .2017 & 1,22 & 1,28 & 1,31 & 1,36 \\
\hline \multirow{5}{*}{ mediana } & 23.05 .2016 & 1,52 & 1,58 & 1,57 & 1,60 \\
& 23.06 .2016 & 1,50 & 1,57 & 1,58 & 1,64 \\
& 23.07 .2016 & 1,33 & 1,38 & 1,51 & 1,58 \\
& 23.09 .2016 & 1,30 & 1,33 & 1,39 & 1,55 \\
& 23.01 .2017 & 1,22 & 1,28 & 1,30 & 1,33 \\
\hline \multirow{5}{*}{ wartość maksymalna } & 23.05 .2016 & 1,70 & 1,74 & 1,65 & 1,70 \\
& 23.06 .2016 & 1,70 & 1,74 & 1,65 & 1,70 \\
& 23.07 .2016 & 1,49 & 1,63 & 1,58 & 1,64 \\
& 23.09 .2016 & 1,50 & 1,63 & 1,56 & 1,60 \\
& 23.01 .2017 & 1,34 & 1,45 & 1,56 & 1,60 \\
\hline \multirow{5}{*}{ wartość minimalna } & 23.05 .2016 & 1,27 & 1,33 & 1,50 & 1,57 \\
& 23.06 .2016 & 1,29 & 1,40 & 1,50 & 1,58
\end{tabular}

Źródło: opracowanie własne na podstawie danych Bloomberg. 


\section{Zmiany poziomu PKB i CPI}

Niemalże w całym 2015 r. nie obserwowano wzrostu przeciętnego poziomu cen w brytyjskiej gospodarce. Indeks CPI był bliski zeru. Pierwsza połowa 2016 r. przyniosła nieznaczny wzrost inflacji, do poziomu ok. 0,5 proc. W okresie nastęującym po referendum (07.2016-01.2017) zaobserwowano silny trend wzrostowy indeksu cen dóbr i usług konsumpcyjnych, mianowicie jego poziom wzrósł z 0,5 proc. do wysokości 1,8 proc. (rys. 4). Tym samym poziom indeksu CPI zbliżył się do wysokości celu inflacyjnego Banku Anglii wynoszacego 2 proc. (Bank of England, Monetary Policy Framework 2017). Od początku analizowanego okresu do sierpnia 2016 r. bazowa stopa procentowa banku centralnego Wielkiej Brytanii pozostawała na niezmienionym poziomie 0,5 proc. (rys. 4). Czwartego sierpnia 2016 r., po niemalże siedmiu i pół roku, władze Banku Anglii zdecydowały się obniżyć poziom stopy procentowej o 25 punktów bazowych (Bank of England, Official Bank Rate History 2017). Warto zauważyć, iż decyzja ta została podjęta w momencie wzrostu przeciętnego poziomu cen w gospodarce. Można wnioskować, że ultraniski poziom inflacji nie mógł stanowić bezpośredniego powodu obniżenia bazowej stopy procentowej w Wielkiej Brytanii.

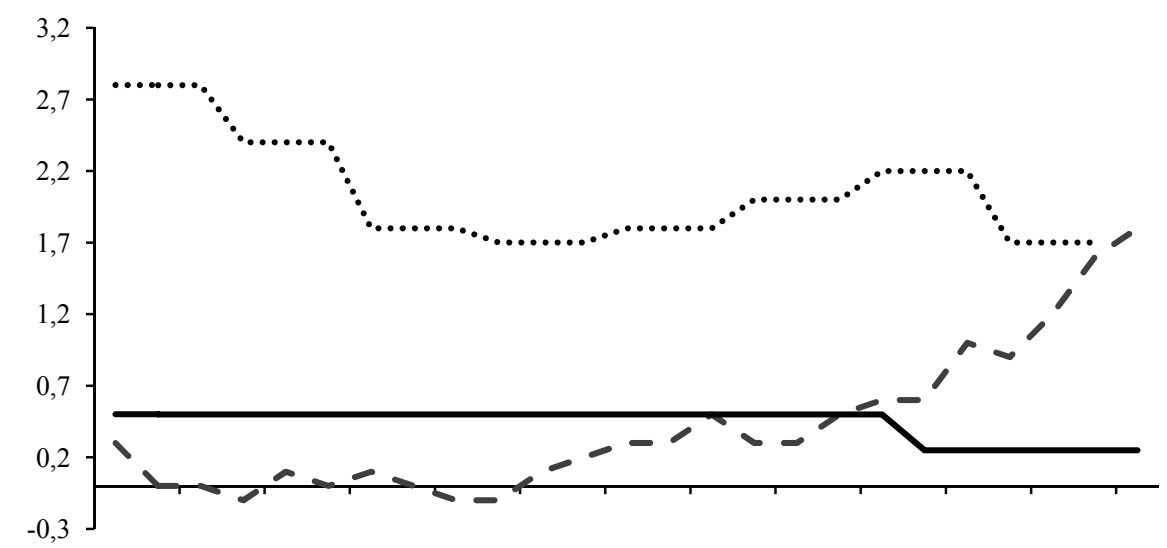

sty 15 mar 15 maj 15 lip 15 wrz 15 lis 15 sty 16 mar 16 maj 16 lip 16 wrz 16 lis 16 sty 17

$$
\text { - }- \text { CPI } \quad \cdots . . . \cdot \text { PKB bazowa stopa procentowa }
$$

Rys 4. Poziom wzrostu gospodarczego, inflacji oraz bazowej stopy procentowej w Wielkiej Brytanii w okresie $01.2015-01.2017$

Fig. 4. GDP growth rate, CPI level, and Official Bank Rate level in the United Kingdom in the period 01.201501.2017

Źródło: Opracowanie własne na podstawie danych Bloomberg oraz Banku Anglii.

Wprowadzenie bardziej ekspansywnej polityki monetarnej należy łączyć $\mathrm{z}$ konsekwencjami wyniku referendum, tj. zarówno $\mathrm{z}$ obniżeniem tempa wzrostu gospodarczego oraz niekorzystnymi prognozami ze strony niezależnych instytucji finansowych dotyczącymi wzrostu PKB w latach 2017-2020 (rys. 5). W celu pobudzenia gospodarki, Bank Anglii zdecydował się również na rozszerzenie programu luzowania ilościowego o 70 mld GBP (do wysokości 435 mld GBP), którego celem jest wywołanie 
wzrostu podaży pieniądza, a w konsekwencji spowodowanie wzrostu inwestycji i konsumpcji w brytyjskiej gospodarce (na skutek zwiększonej akcji kredytowej sektora bankowego) (Bank of England, Quantitative easing..., 2017).

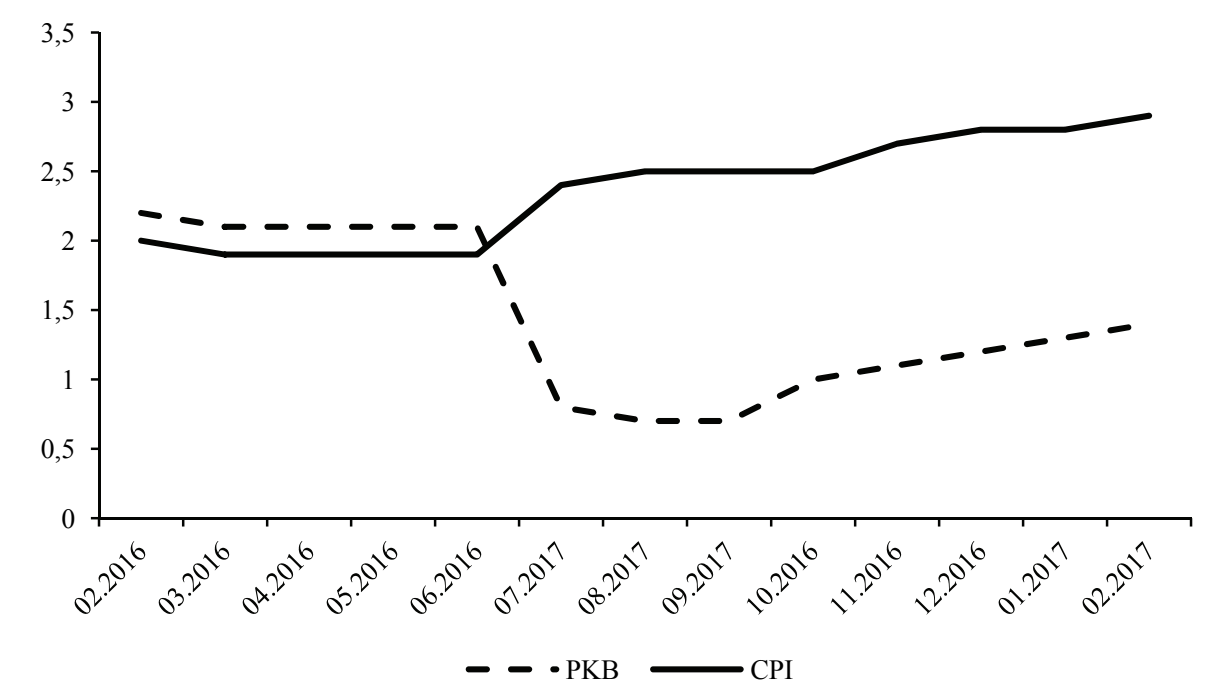

Rys. 5. Prognozowana wysokość tempa wzrostu gospodarczego oraz inflacji w Wielkiej Brytanii w 2017 r. (na podstawie miesięcznych prognoz z okresu 02.2016-02.2017)

Fig. 5. Forecasted GDP growth rate and CPI level in the United Kingdom in 2017 (based on monthly forecasts from the period $02.2016-02.2017$ )

Źródło: opracowanie własne na podstawie Forecasts for the UK economy.

Wyniki referendum wpłynęły, bezpośrednio lub pośrednio, na zmiany prognoz wysokości tempa wzrostu PKB i poziomu inflacji CPI w 2017 r. Predykcje niezależnych ośrodków ekonomicznych przeprowadzane na zlecenie brytyjskiego rządu w miesiącach po referendum wskazały na istotne obniżenie tempa wzrostu gospodarczego do poziomu poniżej 1 proc. (z poziomu 2,1 proc. wzrostu PKB w czerwcu 2016). Prognozowany poziom CPI w 2017 r. wzrastał w okresie po referendum. Prognozy z lutego 2017 r. wskazywały na przekroczenie celu inflacyjnego Banku Anglii w 2017 r., wynoszącego 2 proc., o 0,9 pkt. proc. (rys. 5).

\section{Spadek aktywności gospodarczej}

Analiza wskaźników koniunktury gospodarczej pozwala na uchwycenie zmian aktywności ekonomicznej (Kolba, Kotkowski 2013). Indeksy aktywności gospodarczej w sektorze wytwórczym - PMI (ang. Purchasing Managers' Indexes) oparte są na miesięcznych badaniach wybranych firm, reprezentujących prywatny sektor gospodarczy. Do obliczenia indeksu PMI wykorzystywane są następujące zmienne, tj. produkcja, nowe zamówienia, zatrudnienie, poziom zapasów oraz ceny. Indeks PMI ustalany jest dla sektora produkcyjnego, budowlanego, sprzedaży detalicznej oraz sektora usług (IHS Markit, 2017). 
Większość ekonomistów przyjmuje, że wartość wskaźnika PMI powyżej 50 pkt. należy utożsamiać z ożywieniem gospodarczym (Bretz, 1990). Na rys. 6 zaprezentowano kształtowanie się miesięcznego wskaźnika PMI dla sektora produkcyjnego (ang. Manufacturing PMI), sektora usług (ang. Services PMI) oraz całkowitego indeksu PMI (ang. PMI Composite) będąca połączeniem indeksów PMI dla przemysłu i usług w Wielkiej Brytanii w latach 2015-2016.

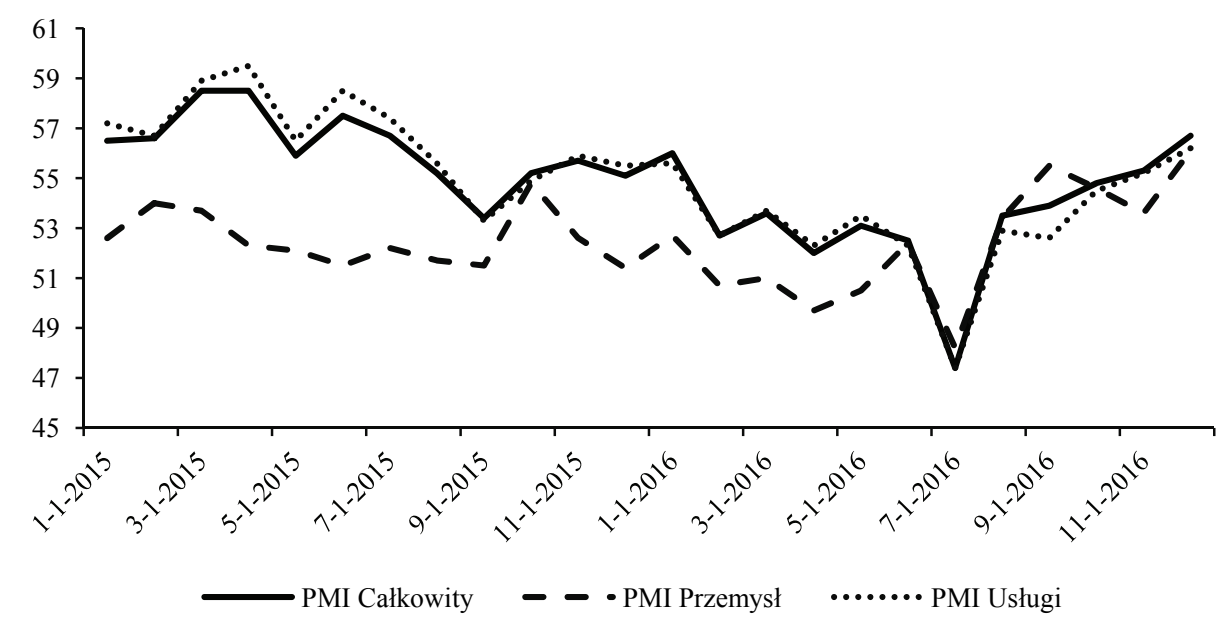

Rys. 6. Poziom wskaźników PMI w Wielkiej Brytanii w latach 2015-2016

Fig. 6. Purchasing Managers' Indexes levels in the United Kingdom in the period 2015-2016

Źródło: opracowanie własne na podstawie danych Bloomberg.

W analizowanym okresie wartość wskaźników PMI (rys. 6) utrzymywała się powyżej 50 pkt., co należy utożsamiać z występowaniem ożywienia gospodarczego w Wielkiej Brytanii. Wyjątek stanowił poziom PMI zaobserwowany w lipcu 2016, tj. bezpośrednio po ogłoszeniu wyników referendum. Dane z okresu sierpień - grudzień 2016 r. wskazują na uspokojenie nastrojów brytyjskich podmiotów gospodarczych. Ostatnia odczytana w analizowanym okresie (grudzień 2016) wartość PMI (zarówno w sektorze usług jak i produkcyjnym) była zbliżona do wartości sprzed roku (grudzień 2015) i dwóch lat (styczeń 2015). Przedstawione na rys. 6 wartości PMI wskazuja, że poza wyżej wskazanym szokiem, decyzja podjęta przez Brytyjczyków w referendum nie doprowadziła do długoterminowej zmiany poziomu aktywności gospodarczej przedsiębiorstw w Wielkiej Brytanii.

\section{Destabilizacja finansów publicznych}

Prognoz dotyczących stanu finansów publicznych Wielkiej Brytanii nie można uznać za optymistyczne. Brytyjski minister finansów, Philip Hammond, oficjalnie zrezygnował z realizacji ambitnego celu eliminacji deficytu budżetowego do roku fiskalnego 2019-2020, zapowiedzianego przez swojego poprzednika George'a Osborne'a. W opinii Hammonda, zrównoważona polityka budżetowa rządu wydaje się być zbyt restrykcyjna, biorąc pod 
uwagę występującą niepewność gospodarczą w konsekwencji wyników referendum z 23 czerwca 2016 r. (Austerity lite, 2016).

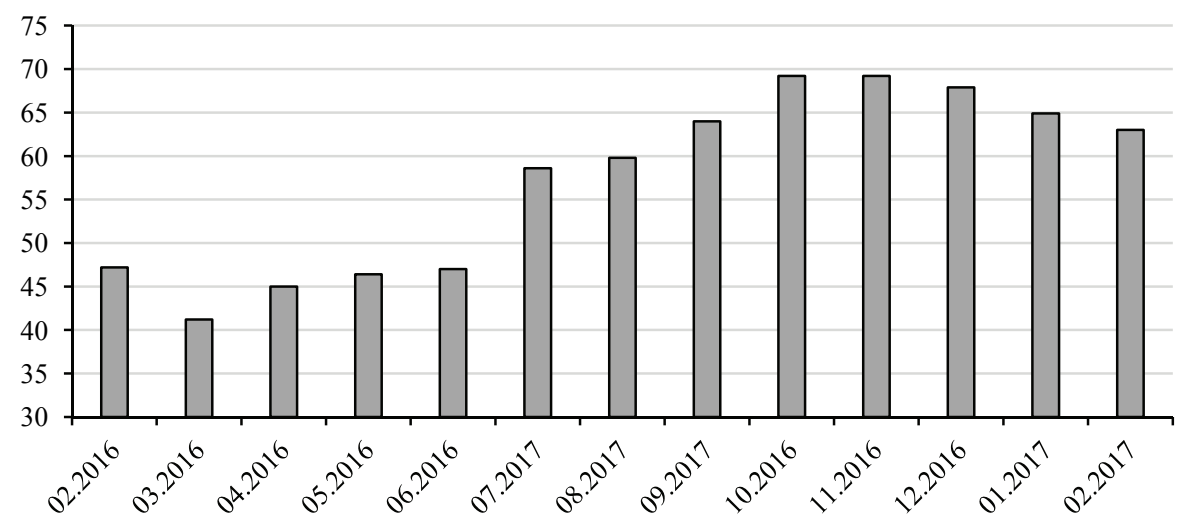

Rys. 7. Prognozowana wysokość deficytu sektora finansów publicznych w Wielkiej Brytanii w 2017 r. (na podstawie miesięcznych prognoz z okresu 02.2016-02.2017)

Fig. 7. Forecasted British general government deficit in 2017 (based on monthly forecasts from the period 02.2016-02.2017)

Źródło: opracowanie własne na podstawie Forecasts for the UK economy.

Rys. 7, prezentujący prognozy z okresu 02.2016-02.2017 dotyczące wysokości deficytu sektora finansów publicznych w 2017 r., pokazuje, że wysokość prognozowanego ujemnego salda brytyjskich finansów publicznych w mld GBP wzrosła o ponad 30 proc. pomiędzy czerwcem 2016 a lutym 2017 r. Najbardziej negatywne prognozy zaobserwowano w październiku i listopadzie 2016 r., w konsekwencji ogłoszenia przez premier Wielkiej Brytanii twardego Brexitu jako jedynej możliwej formy przyszłej relacji z Unią Europejską.

Dużym obciążeniem dla brytyjskich finansów publicznych mogą okazać się dodatkowe wydatki związane $\mathrm{z}$ opuszczeniem struktur Unii Europejskiej. Analiza przeprowadzona przez Financial Times, wykazała, że wysokość rachunku, który UE wystawi Wielkiej Brytanii po wystapieniu Brexitu, może być zbliżony do 20 mld euro. Dokładna wartość jest wciąż niemożliwe do ustalenia, ponieważ uzależniona jest od warunków politycznych (UK faces..., 2016).

\section{Podsumowanie}

W artykule przedstawiono wpływ wyniku referendum z 23 czerwca 2016 r. dotyczącego wyjścia Wielkiej Brytanii z Unii Europejskiej na stan gospodarki i finansów tego kraju. Perspektywa Brexitu zszokowała opinię publiczną na całym świecie. Realna możliwość odłączenia się Wielkiej Brytanii z UE wywołała gwałtowny wzrost wartości indeksu niepewności polityki gospodarczej (EPU). Wysoki poziom niepewności ekonomicznej i finansowej wywołał szereg negatywnych konsekwencji dla brytyjskiej gospodarki. Przyczynił się do bardzo silnej deprecjacji funta szterlinga. Kurs USD/GBP 
spadł poniżej poziomów osiaganych $\mathrm{w}$ trakcie ataku spekulacyjnego przeprowadzonego przez George'a Sorosa w 1992 r., inwazji na Irak w 2003 r., czy kryzysu finansowego w latach 2008-2009. Wynik referendum miał bezpośredni lub pośredni wpływ także na inne sfery działalności ekonomicznej Wielkiej Brytanii. Wzrost średniego poziomu cent dóbr i usług konsumpcyjnych oraz spadek tempa wzrostu gospodarczego można wiązać z perspektywą Brexitu. W celu ożywienia gospodarki Wielka Brytania zdecydowała się na wprowadzenie bardziej ekspansywnej polityki monetarnej, tj. obniżyła poziom bazowej stopy procentowej o 25 punktów bazowych oraz rozszerzyła program luzowania ilościowego. Bank podjął te kroki bezpośrednio po 23 czerwca 2016 r. Poziom aktywności gospodarczej w sektorze wytwórczym uległ jednakże tylko krótkookresowemu obniżeniu w konsekwencji wyniku referendum. Perspektywa Brexitu miał również negatywny wpływ na stan finansów publicznych Wielkiej Brytanii. Wysokość prognozowanego ujemnego salda finansów publicznych w 2017 r. wzrosła pomiędzy czerwcem 2016 r. a lutym 2017 r. o ponad 30 proc., co również można odbierać jako skutek decyzji Brytyjczyków o wyjściu z Unii Europejskiej.

\section{Literatura}

Austerity lite (2016). The Economist. October $8^{\text {th }}-14^{\text {th }} 2016,12$.

Baker S., Bloom N., Davis S. (2015). Measuring Economic Policy Uncertainty. NBER Working Paper Series, 21633.

Baker S., Bloom N., Davis S. (2016). Measuring Economic Policy Uncertainty. The Quarterly Journal of Economics, 131 (4), 1593-1633.

Bank of England. Monetary Policy Framework. Pobrane 10 lutego 2017 r. z: http://www.bankofengland.co.uk/monetarypolicy/Pages/framework/framework.aspx.

Bank of England. Official Bank Rate History. Pobrane 10 lutego 2017 r. z: http://www.bankofengland.co.uk/boeapps/iadb/Repo.asp.

Bank of England. Quantitative easing and the Asset Purchase Facility. Pobrane 10 lutego 2017 r. z: http://www.bankofengland.co.uk/markets/Pages/apf/default.aspx.

Bretz, R. J. (1990). Behind the Economic Indicators of the NAPM Report on Business. Business Economics, 25 (3), 42-48.

Czech, K. (2016). Anomalia premii terminowej na rynku jena japońskiego. Wydawnictwo SGGW, Warszawa.

Economic Policy Uncertainty. Pobrane 10 lutego 2017 r. z: http://www.policyuncertainty.com/methodology.html.

Forecasts for the UK economy: a comparison of independent forecasts (2017), 358, February 2017. Pobrane 28 lutego 2017 r. z: https://www.gov.uk/government/uploads/system/uploads/attachment_data/file/591911/ Forecast for the UK Economy Feb 2017.pdf.

IHS Markit. Pobrane 10 lutego 2017 r. z http://www.markit.com/Product/PMI.

Jehle, G.A., Reny P. J. (2000). Advanced Microeconomic Theory. Prentice Hall, New York.

Kolba, P.M., Kotkowski, R. (2013). Wskaźniki cyklu koniunkturalnego a krótkookresowe prognozy polskiej produkcji przemysłowej. Oeconomia Copernicana, 3, 65-79.

Krugman, P., Rogoff, K., Fischer, S., McDonough, W. (1999). Currency Crises. In: Feldstein M. International Capital Flows. University of Chicago Press, 421-466.

May warned over 'hard Brexit' as Pound flash crash highlights fears (2016). Financial Times Weekend. Europe Edition. 08-09.10.2016, s. 1.

Plakandaras, V., Gupta, R., Wohar, M. (2016). The Depreciation of the Pound Post-Brexit: Could it have been Predicted? University of Pretoria. Department of Economics Working Paper Series, 1-15.

Schiereck, D., Kiesel, F., Kolaric, S. (2016). Brexit: (Not) another Lehman moment for banks? Finance Research Letters, 19, 291-297.

Steinberg, J. (2017). Brexit and the Macroeconomic Impact of Trade Policy Uncertainty. Working Paper, University of Toronto.

Theresa May kicks off Brexit. (2016). The Economist. Pobrane 2 lutego 2017 r. z: http://www.economist.com/news/britain/21708078-prime-minister-promises-invoke-article-50-end-marchjust-how-hard-brexit. 
Truman, E.M. (2002). Economic policy and exchange rate regimes: what have we learned in the ten years since Black Wednesday? London School of Economics.

UK faces $€ 20$ bn Brexit divorce bill in Brussels budget wrangle. (2016). Financial Times. European Edition. 13.10.2016, 1 .

Wielechowski, M., Czech, K. (2016). Brexit related uncertainty for United Kingdom economy. Acta Scientarum Polonorum, 15(4), 171-183. 